\title{
Bioavailability of vitamin D3 in non-oily capsules: the role of formulated compounds and implications for intermittent replacement
}

\author{
Biodisponibilidade da vitamina D3 em cápsulas não \\ oleosas: o papel das formulações manipuladas e as \\ implicaçōes para a substituição intermitente
}

Iara Maria Gomes Coelho', Luena Dias de Andrade', Lunnara Saldanha'², Erik Trovão Diniz² ${ }^{2}$ Luiz Griz², Francisco Bandeira ${ }^{2}$

\begin{abstract}
Objective: To evaluate the bioavailability of vitamin $D$ in capsules as compared with oily drops in nuns living in a closed community with very low sun exposure. Methods: A randomized, 2 x 2 crossover, open clinical trial was conducted, with 18 nuns aged between 20 and 75 years. Samples were collected in the fasting state and at 4, 8, 12 and 24 hours following the administration of capsules and oily drops (both containing vitamin D3 66,000 UI plus vitamin A 13,200 $\mathrm{UI})$ to determine serum 25 hydroxivitamin D concentrations (25OHD), at baseline and 90 days after. The evaluation was based on the maximum concentration $\left(\mathrm{C}_{\max }\right)$ and area under the curve $\left(A \cup C_{0-24}\right)$. Results: The capsule formulation presented $\mathrm{C}_{\max }$ and $\mathrm{AUC}_{0-24}, 5.78 \%$ and $0.76 \%$, respectively, greater than the oily drops formulation. Conclusion: Both formulations were within the limits for a bioequivalence study, namely $\mathrm{C}-90 \%$ for $\mathrm{C}_{\max }$ and $\mathrm{AUC}_{0-24^{\prime}}$ and the drugs were considered bioequivalent. Arq Bras Endocrinol Metab. 2010;54(2):239-43
\end{abstract}

\section{Keywords}

Bioavailability; vitamin D; pharmacokinetics

\section{RESUMO}

Objetivo: Avaliar a biodisponibilidade da vitamina D3 em cápsulas, comparando com gotas oleosas, em religiosas que vivem em comunidade fechada com baixa exposição solar. Métodos: Ensaio clínico aberto, aleatório e cruzado 2 x 2, com 18 religiosas ( $20-75$ anos de idade). As amostras foram coletadas em jejum e 4, 8, 12 e 24 horas após a administração de cápsulas e de gotas oleosas (ambos contendo 66.000 UI de vitamina D3 e 13.200 UI de vitamina A) para dosagem da 25 hidroxivitamina $\mathrm{D}(25 \mathrm{OHD})$, em data base e 90 dias após. A avaliação baseouse nos resultados da concentração máxima $\left(C_{\text {máx }}\right)$ da $250 H D$ e da área sob a curva $\left(\mathrm{ASC}_{0-24}\right)$. Resultados: $A$ análise descritiva desses parâmetros demonstrou que a cápsula apresentou $\mathrm{C}_{\text {máx }}$ e $\mathrm{ASC}_{0-24}$ de 5,78\% e 0,76\% a mais que as gotas oleosas, respectivamente. Conclusão: Ambas as formulações encontravam-se dentro dos limites de aceitação em estudo de bioequivalência IC- $90 \%$ para $\mathrm{C}_{\text {máx }}$ e ASC ( $\left.{ }_{0-24}\right)$, daí as drogas serem consideradas bioequivalentes. Arq Bras Endocrinol Metab. 2010;54(2):239-43

Descritores

Biodisponibilidade; vitamina D; farmacocinética
1 Ambulatório de Endocrinologia Ginecológica, Hospital Agamenon Magalhães, Sistema Único de Saúde (SUS), Universidade de Pernambuco (UPE), Recife, PE, Brasil ${ }^{2}$ Divisão de Endocrinologia e Diabetes, Hospital Agamenon Magalhães, SUS/ UPE, Recife, PE, Brasil
Correspondence to: lara Maria Gomes Coelho Rua Setubal, 596, ap. 602 51030-010 - Recife, PE, Brasil csamarques@hotmail.com

Received on Nov/16/2009 Accepted on Feb/28/2010 


\section{INTRODUCTION}

The prevention of vitamin D deficiency and insufficiency remains a priority of both domestic and international health services (1-3). Different administration protocols have been used taking into account the long half-life of vitamin $\mathrm{D}$, since there is interest in administering vitamin D3 intermittently. A systematic review evaluated several studies since 1980, with intermittent doses of vitamin D, ranging from 100,000 IU per month to 4,000 IU daily, and concluded that this treatment option is safe, effective, simple to use and has better compliance (4).

Vitamin D is known to be liposoluble, and its relative bioavailability could result in unfavorable conditions when administered in solid form (capsules), since the process of its release is a factor limiting the rate of absorption, bearing in mind that bioavailability is related not only to the pharmaceutically active molecules, but also, and most importantly, to the formulation and excipients used. The aim of this study was to evaluate whether vitamin $\mathrm{D}$ would achieve bioavailability within the limits of safety and efficacy when administered in non-oily capsules.

\section{PATIENTS AND METHODS}

An open, randomized, $2 \times 2$ crossover trial was conducted in healthy nuns living in a closed community whose garments exposed only 10\% of the body (face, hands and feet), who shared the same eating habits and who were engaged, in a disciplined manner, in outdoor work (gardening) for 1 hour every 20 days, thereby having very low sun exposure. These nuns spontaneously sought treatment at the gynecology outpatient clinic of Agamenon Magalhães Hospital (HAM).

The inclusion criteria were as follows: nuns with a low sun exposure; members of the same religious order (Carmelites); aged between 20 and 75 years with body mass index between 21.8 and $29 \mathrm{~kg} / \mathrm{m}^{2}$, who spontaneously agreed to participate in the trial after giving informed consent. The exclusion criteria were as follows: systemic inflammatory or malignant disease, hepatic or renal failure, uncontrolled hypo- or hyperthyroidism, the use of drugs that are known to affect bone metabolism such as bisphosphonates, glucocorticoids and anticonvulsants. Eighteen patients were randomly assigned and two dates were set with 90 days of interval between them in order to measure serum $25 \mathrm{OHD}$ concentrations in response to both intervention therapies.

Blood samples were taken in the fasting state and at $4,8,12$ and 24 hours after the administration of both drugs, with the second series of samples being taken after administering the drug not given in the first phase of the study, in a cross-over design.

The intervention therapies were as follows: 1) Oily drops - 13,200 IU of vitamin A acetate and 66,000 IU of vitamin D3 (Aderogil - Sanofi Aventis) in excipient peanut oil - (reference). 2) Manipulated capsules - 13,200 IU of vitamin A acetate and 66,000 IU of vitamin D3 in lactose excipient - (test). The interval between the two periods of administration (washout time) was 90 days in order to eliminate the residual effects of the formulations administered. This time was determined based on the half-life of the drug administered and the liposoluble characteristics of vitamin D3 (5).

Serum $25 \mathrm{OHD}$ was measured by radioimmunoassay (DiaSorin, Inc, Stillwater, MN, USA). The lowest detectable limit was $1.5 \mathrm{ng} / \mathrm{mL}(3.7 \mathrm{nmol} / \mathrm{L})$, and the intra-assay and inter-assay coefficients variation were $6 \%$ and $8 \%$, respectively. On both occasions fifteen days after the administration of the drugs, a clinical assessment was made in all the subjects, and there were no complaints or side-effects being associated with the therapy. The clinical study protocol was approved by the HAM Ethics in Research Committee.

\section{COMPARATIVE BIOAVAILABILITY - PHARMACOKINETICS ANALYSIS}

The pharmacokinetic measures evaluated to determine bioavailability derived directly from the curve of serum concentration of the drug versus time, by quantifying the biological samples in relation to the previously established collection times $(0,4,8,12$ and 24 hours). The design of this study provided the subjects with their own control, reducing external factors in the analysis of the parameters that define bioavailability (speed and amount of drug entering the bloodstream). The following pharmacokinetic measurements were evaluated: plasma concentration of the curve drug versus time $\left(\mathrm{AUC}_{0-24}\right)$, the maximum plasma concentration achieved $\left(\mathrm{C}_{\max }\right)$, and the time to peak concentration $\left(\mathrm{T}_{\max }\right)$. All pharmacokinetic parameters were calculated using the statistical software WinNolin 5.0.

\section{STATISTICAL ANALYSIS}

The pharmacokinetic parameters $\mathrm{AUC}_{0-24}$ and $\mathrm{C}_{\max }$ were converted into a natural logarithm for the analysis of variance (ANOVA), and the confidence inter- 
vals were also calculated (CI). The construction of the confidence interval of $90 \%$ for the difference of means was based on the least square means of the data converted into logarithms and the residual mean square of this ANOVA test. The antilogarithms of the confidence limits obtained constitute the $90 \%$ CI for the ratio of geometric means between the test and reference drugs. The conclusion of mean bioequivalence is achieved when this confidence interval is between $80 \%$ and $125 \%$. This method is equivalent to the procedure of two one-tailed tests corresponding to the null hypothesis of bioequivalence (6).

\section{RESULTS}

Figure 1 shows the mean serum $25 \mathrm{OHD}$ concentrations after the reference and test drugs. Seventy-eight percent of the study patients had 25OHD levels below $30 \mathrm{ng} / \mathrm{mL}$ in the basal state. In the descriptive analysis of the pharmacokinetic parameters presented in Tables $\mathrm{l}$ and 2, the test formulation presented a $\mathrm{C}_{\max } 5.78 \%$ higher than the reference drug, while the $\mathrm{AUC}_{0-24}$ showed an absorption $0.76 \%$ greater than the reference formulation. In relation to the $\mathrm{T}_{\max }$, very similar times were observed $-15.11 \mathrm{~h}$ and $14.00 \mathrm{~h}$ - respectively, for the test and reference formulations.

The confidence interval for the mean $\mathrm{C}_{\max }$ was 96.91\% (lower limit) and $111.57 \%$ (upper limit), according to the classic confidence interval. Values according to the Westlake test were 90.22 (lower limit) and 109.78 (upper limit). The mean $\mathrm{C}_{\max }$ of the reference drug (oily drops) calculated by the method of the least squares was 3.30 and 3.34 for the test drug (capsules $)$, resulting in a ratio $\left(\mathrm{C}_{\max }\right.$ Test $/ \mathrm{C}_{\max }$ Reference $)$ of 103.98 with a $\mathrm{C}_{\max }$ test power of $99.91 \%$ and an AUC of $99.99 \%$. The $\mathrm{T}_{\max }$ values were 11.78 and 12.67 for the test and reference drugs, respectively. We also calculated the classic confidence interval for the $\mathrm{AUC}_{0-24}$ values, yielding of 93.44 and 104.08 for the lower and upper limits, respectively. The values of the confidence interval using Westlake were 94.25 (lower limit) and 105.75 (upper limit). The mean $\mathrm{AUC}_{0-24}$ calculated by the least squares method of the reference and test drugs was 6.33 and 6.32 , respectively. The ratio between the means $\left(\mathrm{AUC}_{0-24}\right.$ Test/AUC ${ }_{0-24}$ Reference) was 98.62, showing a test power of $99.99 \%$.

The statistical calculations for the $\mathrm{C}_{\max }$ and $\mathrm{AUC}_{0-24}$ confidence intervals were discriminatory for the assertion of bioequivalence as the power of the statistical test in both cases proved to be high, thus demonstrating that the number of volunteers (7) was sufficient to obtain the desired minimum power of $80 \%$.

On the basis of the results obtained, the two drugs were considered bioequivalent, since the $90 \%$ CI for the ratio between the means of the $\mathrm{C}_{\max }$ and AUC pharmacokinetic parameters were between $80 \%$ and $125 \%$ and thus interchangeable (8).

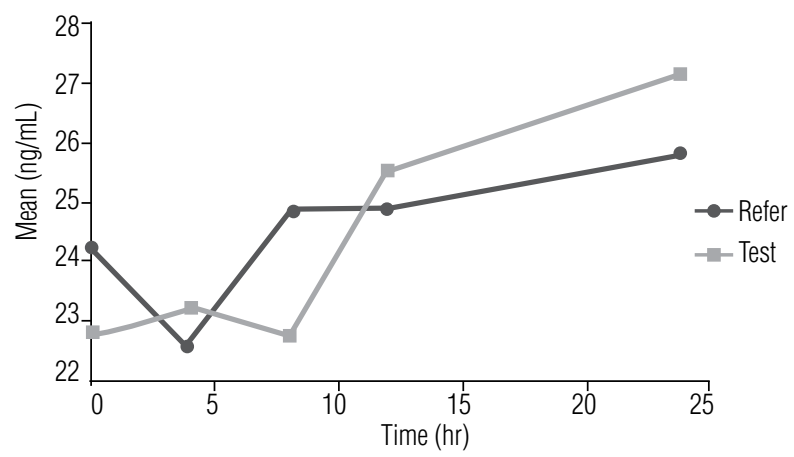

Figure 1. Mean serum $250 \mathrm{HD}$ after the test and reference compounds

Table 1. Mean pharmacokinetics parameters of 18 volunteers for the reference drug $(\mathrm{R})$

\begin{tabular}{|c|c|c|c|}
\hline & $C_{\max }(n g / m L)$ & $\mathrm{T}_{\max }(\mathbf{h})$ & $\begin{array}{c}\left.\operatorname{AUC}_{(0-24)}\right) \\
(\mathrm{h} \mathrm{ng} / \mathrm{mL})\end{array}$ \\
\hline Mean & 28.51 & 14 & 592.07 \\
\hline Geometric mean & 27.34 & 9.80 & 556.51 \\
\hline DP & 8.44 & 8.92 & 182.86 \\
\hline CV & 29.60 & 63.70 & 30.88 \\
\hline Minimum & 17.40 & 0.00 & 359.80 \\
\hline Maximum & 45.20 & 24.00 & 949.20 \\
\hline
\end{tabular}

Table 2. Mean pharmacokinetic parameters of 18 volunteers for the test $\operatorname{drug}(\mathrm{T})$

\begin{tabular}{lccc}
\hline & $\mathbf{C}_{\text {max }}(\mathbf{n g} / \mathbf{m L})$ & $\mathbf{T}_{\text {max }}(\mathbf{h})$ & $\begin{array}{c}\mathbf{A U C}\left(_{\mathbf{0} 24}\right) \\
(\mathbf{h ~ n g / m L})\end{array}$ \\
\hline Mean & 30.16 & 15.11 & 596.57 \\
Geometric mean & 28.43 & 13.00 & 558.68 \\
DP & 10.56 & 7.71 & 233.92 \\
CV & 35.01 & 51.00 & 39.21 \\
Minimum & 11.70 & 4.00 & 243.00 \\
Maximum & 56.50 & 24.00 & 1260.60 \\
\hline
\end{tabular}

\section{DISCUSSION}

There are important concerns regarding bioavailability, bioequivalence and interchangeability of the various formulations used in therapeutic compounds, for which 
there are many factors that can modify the release, dissolution and absorption of the drug in the body. There are several ways of evaluating the bioavailability of drugs, but the recommended method is the quantitative determination of the drug and/or its metabolite in body fluids (blood, plasma) as function of time, due to its greater precision and accuracy.

Vitamin D deficiency is common in individuals of various ethnic groups around the world, in both developing and developed countries, even in those close to the equator (9). New applications for vitamin D are being sought in an attempt to present them for major public health problems such as osteoporosis, which increases with advancing age, autoimmune diseases, type 1 and type 2 diabetes, and cancers, among others.

Muindi and cols. (10) conducted a comparative pharmacokinetic study comparing an oily liquid calcitriol formulation administered to patients with advanced cancer with the soft gelatin capsule formulation and concluded that the liquid formulation does not offer any advantages in terms of pharmacokinetics or bioavailability over the capsule formulation. The results indicated that calcitriol in liquid form failed to attain $\mathrm{C}_{\max }$ and AUC values associated with an anti-tumor action (10).

A study conducted in the city of Boston set out to evaluate whether vitamin $\mathrm{D}$, would attain bioavailability within the levels of safety and efficacy when contained in non-fatty products, such as skimmed milk, orange juice, and corn oil on toast, comparing them with whole milk enriched with that vitamin. The authors concluded that the level of fat in the milk does not affect the bioavailability of vitamin D (11).

Our data show that the test drug (capsules), when compared with the reference drug (oily drops), presented a $\mathrm{C}_{\text {max }}$ and an $\mathrm{AUC}_{0-24}, 5.78 \%$ and $0.76 \%$, respectively, higher than the reference drug. It was also observed that the $\mathrm{T}_{\max }$ showed very similar times, namely $15.11 \mathrm{~h}$ and $14 \mathrm{~h}$, respectively, for the test and reference drugs. The above data indicate that the fact that the vehicle used in the administration of the capsules is not of lipophilic origin it does not affect the bioavailability of vitamin D.

From the results of the basal concentrations of $25 \mathrm{OHD}$, we concluded that $77.75 \%$ of the nuns had vitamin $\mathrm{D}$ deficiency. We can thus state that the brief and casual exposure of the face, arms and hands to sunlight may not provide certain individuals with their vitamin $\mathrm{D}$ requirements, and also that the garments limit exposure to sunlight. This is in agreement with the data reported by Alagol (12), and Abdullah (13) in Turkish and Saudi Arabian women who, due to covering their bodies with clothing, usually have low serum $25 \mathrm{OHD}$ concentrations.

The coefficient of intra-individual variation $(\mathrm{CV})$, of both formulations was less than $35 \%$ for $\mathrm{C}_{\max }$ and $39 \%$ for $\mathrm{AUC}_{0-24}$, demonstrating that vitamin $\mathrm{D}$ is not a drug of high variability (14). As the appropriate size of the sample was dependent on the power of the test (in our study $>80 \%$ ), based on an estimate of the coefficient of individual variation, the sample size was sufficient to accurately determine the equivalence and interchangeability of the two formulations in question.

In conclusion the amount and speed (bioavailability) of vitamin D3 entering the bloodstream is not affected by capsule formulation, which suggests that prophylaxis and treatment of vitamin $\mathrm{D}$ deficiencies may be carried out with manipulated capsules. Considering intermittent high-dose of oral vitamin D3 is as effective as a daily dose (in the same amount) in maintaining adequate serum 25OHD levels, thus improving longterm compliance, our results should have practical implications for the clinical use of vitamin $\mathrm{D}(15,16)$.

Disclosure: no potential conflict of interest relevant to this article was reported.

\section{REFERENCES}

1. Schuch NJ, Garcia VC, Martini LA. Vitamin D and endocrine diseases. Arq Bras Endocrinol Metab. 2009;53(5):625-33.

2. Bandeira F, Griz L, Dreyer P, Eufrazino C, Bandeira C, Freese E. Vitamin D deficiency: a global perspective. Arq Bras Endocrinol Metab. 2006;50(4):640-6.

3. Holick MF. Vitamin D: the underappreciated D-lightful homone that is important for skeletal and cellular health. Curr Opin Endocrinol Diabetes. 2002;9:87-98.

4. Hathcock JN, Shao A, Vieth R, Heaney R. Risk assessment for vitamin D. Am J Clin Nutr. 2007;85:6-18.

5. Van den Berg, H. Bioavailability of vitamin D. Eur J Clin Nutr. 1997;51(1 suppl):S76-9.

6. Anvisa - Agência Nacional de Vigilância Sanitária. [acesso 22 ago 2006]. Disponível em: http://www.anvisa.gov.br/legis/resol/44_77.htm.

7. Tothfalusi L, Endrenyi L, Midha KK, Rawson MJ, Hubbard JW. Evaluation of the bioequivalence of highly-variable drugs and drug products. Pharm Res. 2001;18(6):728-33.

8. Storpirtis S, Marcolongo R, Gasparotto FS, Vilanova CM. A equivalência farmacêutica no contexto da intercambialidade entre medicamentos genéricos e de referência: bases técnicas e científicas. Gerência de Medicamentos Genéricos-Brasil. Agência Nacional de Vigilância Sanitária. São Paulo: (sn), 2004.

9. Pasco JA, Henry MJ, Nichollson GC, Sanders KM, Kotowick MA. Vitamin D status of women in the Geelong Osteoporosis Study: association with diet and casual exposure to sunlight. Med J Aust. 2001;175:401-5. 
10. Muindi JR, Potter DM, Peng Y, Johnson CS, Trump DL. Pharmacokinetics of liquid calcitriol formulation in advanced solid tumor patients: comparison with caplet formulation. Cancer Chemother Pharmacol. 2005;56(5):493-6.

11. Tangpricha V, Koutkia P, Rieke SM, Chen TC, Perez AA, Holick MF. Fortification of orange juice with vitamin $D$ : a novel approach for enhancing vitamin $\mathrm{D}$ nutritional health. Am J Nutr. 2003;77:1478-83.

12. Alagol F, Shihadeh $Y$, Boztepe $H$, Tanakol R, Yarman S, Azizlerli $H$, et al. Sunlight exposure and vitamin $D$ deficiency in Turkish women. J Endocrinol Invest. 2000;23:173-7.
13. Abdullah MA, Salhi HS, Bakry LA, Okamoto E, Abomelha AM, Stevens B, et al. Adolescent rickets in Saudi Arabia: a rich and sunny country. J Pediatr Endocrinol Metab. 2002;15:1017-25.

14. Demirturk E, Oner L. Highly variable drugs in bioavailability and bioequivalence studies. J Pharm Sci. 2002;27(3):165-72.

15. Ilahi M, Armas LA, Heaney RP. The effect of a single large oral dose of cholecalciferol on serum 25-hydroxyvitamin $D$ levels in humans. J Bone Miner Res. 2007;22(Suppl1):560.

16. Bacon CJ, Gamble GD, Horne AM, Reid IR. A comparison of three high dose oral vitamin D3 supplementation regimens. J Bone Miner Res. 2007;22(Suppl):S126-7. 